\title{
KONSEP JIWA PERSPEKTIF AL-QUR'AN
}

\author{
Khaerul Asfar \\ ${ }^{1}$ Institut Agama Islam Muhammadiyah Sinjai \\ E-mail: khaerulasfar86@gmail.com,Tlp: +6285331452680
}

\begin{abstract}
Abstrak
Jiwa adalah makhluk yang diciptakan dan bukan merupakan bahagian dari dzat Allah Swt. Jiwa merupakan kata benda yang berarti roh manusia, nyawa; seluruh kehidupan batin, sesuatu yang utama yang menjadi semangat; maksud sebenarnya, isi yang sebenarnya, arti yang tersirat, buah hati, kekasih, orang (dalam perhitungan penduduk). Penelitian ini bertujuan untuk: (1) Mengetahui hakikat jiwa dan hubungannya dengan ruh, (2) Mengetahui konsep jiwa dalam al-Qur'an. Metode penelitian yang digunakan metode kualitatif yang difokuskan pada penelitian pustaka (library research). Penelitian ini menggunakan pendekatan multidisipliner yang berupaya membahas dan mengkaji objek dari beberapa disiplin ilmu atau mengaitkannya dengan disiplin-disiplin ilmu yang berbeda, di antaranya pendekatan linguistik, historis, sosiologis dan antropologi. Dalam metode pengumpulan data, peneliti mengambil data dari buku tentang jiwa atau ruh dan data dari karya-karya yang memiliki kaitan serta mendukung penilitian ini. Data yang terkumpul kemudian diolah dengan menggunakan metode komparasi dengan teknik analisis isi (content analysis). Hasil penelitian menunjukkan bahwa Jiwa adalah sesuatu yang maujüd (ada). sebagai sesuatu yang berbentuk non-materil, yang mengalir pada diri fisik manusia yang menjadi sebab manusia menjadi hidup, kata jiwa (al-nafs) disebutkan dalam al-Qur'an dengan jumlah lebih dari dua ratus lima puluh kali jauh lebih banyak dari pada kata al-rụh. Kata al-nafs kadang diartikan dengan ruh, dan tidak dengan sebaliknya, ini menunjukkan bahwa hakekat al-nafs (jiwa) berasal dari ruh. Ruh adalah inti dan jiwa adalah bagian dari ruh.
\end{abstract}

Kata Kunci: Al-Qur'an, Jiwa (al-Nafs), Roh (al-Rūḥ)

\section{Pendahuluan}

Manusia dibentuk atas dua unsur yaitu roh dan jasad, kesatuan ini menyebabkan manusia menjadi hidup dan dapat berinteraksi. Melaksanakan urusan duniawi untuk memenuhi kebutuhan hidupnya untuk memuaskan raganya serta menjalankan ibadah kepada Allah Swt untuk memenuhi kebutuhan rohaninya.

Memahami eksistensi ruh bukanlah perkara yang sederhana, dibutuhkan pemahaman terhadap nash al-Qur'an dan hadis yang menerangkan tentang roh dan mengkaji pendapat ulama tentang itu 


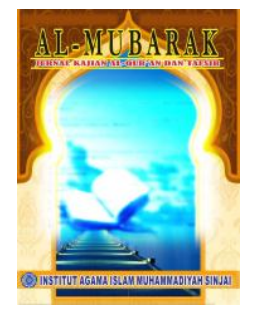

\section{Al-MUBARAK}

Jurmall Kajian Al-Quran \& Tafsir

Volume 4, No. 2, 2019

P-ISSN: 2548-7248

E-ISSN: 2715-5692

Homepage : http://journal.iaimsinjai.ac.id/indeks.php/al-mubarak

Banyak perdebatan diantara ulama dan kalangan berilmu mengenai roh, serta banyak definisi tentang roh yang lahir dari perdebatan ini. Penciptaan roh sebagai makhluk juga terdapat perbedaan pendapat, ada yang menganggap roh sebagai makhluk, sebagaimana makhluk ciptaan Allah Swt. yang lain, tetapi roh itu bersifat ghaib dan bentuknya secara fisik tidak dikenali karena tidak adanya dalil yang menjelaskan secara detail bentuk roh.

Ulama dan filsuf memiliki pandangan yang berbeda dalam menggambarkan tentang roh, serta memiliki pandangan yang berbeda dalam menyikapi keberadaan roh dalam diri manusia dan bagaimana roh itu setelah terjadinya kematian, kematian yang dimaksudkan di sini adalah keluarnya roh dari jasad karena sampainya ajal.

Dengan dalil al-Qur'an yang ada akan digambarkan bagaimana sesungguhnya hakekat roh itu, bagaimana penyikapan yang benar dalam memahami keberadaan roh dan akan menjawab berbagai syubhat yang keliru dalam memahami roh.

\section{Metode}

Untuk mengkaji dan menganalisa objek penelitian dalam penelitian ini, peneliti memaparkan metode penelitian yang akan digunakan. Meliputi: jenis penelitian, metode pendekatan, metode pengumpulan data, dan metode pengolahan data.

\subsection{Jenis Penelitian}

Jenis penelitian ini adalah kualitatif yang bersifat deskriptif. Penelitian ini difokuskan pada penelitian kepustakaan (library research), berfungsi menelusuri, menggambarkan, dan menguraikan ayat-ayat tentang ruh (jiwa) dalam al-Qur'an.

\subsection{Metode Pendekatan}

Untuk mengkaji suatu permasalahan secara lebih komprehensif diperlukan satu, dua atau lebih pendekatan. Semakin banyak pendekatan yang digunakan, kajian tersebut dapat menghasilkan output penelitian yang lebih berkualitas. Pendekatan yang digunakan dalam penelitian ini adalah pendekatan multidisipliner. Pendekatan multidisipliner adalah pendekatan yang digunakan untuk mengkaji suatu persoalan dengan kaca mata berbagai disiplin keilmuan. 


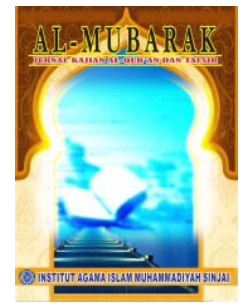

Al-MUBARAK

Jurmall Kajian Al-Quran \& Tafsir

Volume 4, No. 2, 2019

P-ISSN: 2548-7248

E-ISSN: 2715-5692

Homepage : http://journal.iaimsinjai.ac.id/indeks.php/al-mubarak

\subsection{Metode Pengumpulan Data}

Pengumpulan data dalam penelitian ini adalah pembacaan dan penelaahan langsung ke data primer. Penulis juga membaca literatur-literatur lainnya sebagai data sekunder yang mempunyai kaitan dengan penelitian ini. Data yang ditulis dan dikumpulkan oleh penulis menggunakan huruf transliterasi Arab ke Latin disesuaikan dengan penyebutan huruf-huruf vocal dan diftong. Penulisan ayat alQur'an dan penghitungan lafal menggunakan alat bantu berupa al-Maktabah alSyāmilah dalam perangkat komputer.

Pengumpulan data dilakukan dengan cara mengutip, menyadur, dan mengulas literatur yang memiliki relevansi dengan masalah yang dibahas, baik yang bersumber dari buku-buku klasik, buku-buku kontemporer, artikel-artikel dan karya ilmiah yang mempunyai kaitan dengan penelitian ini.

\subsection{Metode Pengolahan dan Analisis Data}

Penelitian ini bersifat kajian kepustakaan (library research) yang bersifat kualitatif, sehingga membutuhkan teknik interpretasi data. Adapun teknik interpretasi data dalam penelitian ini adalah:

a. Teknik interpretasi tekstual, adalah memahami data dengan melihat langsung teks-teksnya. Dalam penelitian ini, teknik interpretasi tersebut digunakan untuk memahami data primer apa adanya sesuai yang tercantum dalam kitab tafsir al-Qur'an.

b. Teknik interpretasi intertekstual adalah memahami data primer dengan melihat data-data lainnya sebagai bahan pertimbangan dan komparatif. Dalam penelitian ini, teknik interpretasi tersebut digunakan untuk memahami data primer dengan membandingkannya dengan data sekunder lainnya yang berhubungan dengan masalah yang dibahas.

Dalam mengolah dan menganalisis data-data yang terdapat pada kitab tafsir al-Qur'an, penulis menggunakan analisis isi (content analysis) yang bersifat kualitatif, yang biasa disebut analisis wacana. Analisis wacana merupakan sebuah analisis yang mencari dan menfokuskan bagaimana sebuah data dikatakan (how), bukan apa yang dikatakan (what). 


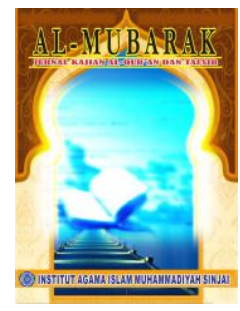

Al-MUBARAK

Jurmall Kajian Al-Quran \& Tafsir

Volume 4, No. 2, 2019

P-ISSN: 2548-7248

E-ISSN: 2715-5692

Homepage : http://journal.iaimsinjai.ac.id/indeks.php/al-mubarak

\section{Pembahasan}

\subsection{Pengertian Jiwa (al-Nafs)}

Jiwa merupakan kata benda yang berarti roh manusia, nyawa; seluruh kehidupan batin, sesuatu yang utama yang menjadi semangat; maksud sebenarnya, isi yang sebenarnya, arti yang tersirat, buah hati, kekasih, orang (Tim Reality, Kamus Terbaru Bahasa Indonesia, 2008: 215).

Jiwa dari akar kata bahasa Arab, yaitu kata al-nafs. Al-nafs (nün-fä-sin) menunjukkan arti keluarnya angin lembut bagaimanapun adanya. Al-nafs juga diartikan darah, karena seseorang apabila kehilangan darah maka ia kehilangan jiwanya (Abū al-Husain Aḥmad ibn Fāris ibn Zakariyā, Juz V: 460), atau hati (qalb) dan sanubari (damir), padanya ada rahasia yang tersembunyi. Juga berarti ruh (Asyraf Ṭāhā Abū al-Dahab, 2002: 619-620). Dalam al-Mu'jam al-Falsafí, kata al-nafs diartikan dengan merujuk kepada tiga versi pendapat; Aristoteles, dengan permulaan kehidupan (vegetative), Kelompok Spiritual (al-rūhiyyūn) mengartikannya sebagai jauhar rụhị (substansi ruh), dan Des Cartes mengartikan sebagai jauhar mufakkir (substansi berfikir) (Majma' al-Lugah al-'Arabiyah, 1983: 204).

Berdasarkan uraian di atas dapat dipahami bahwasanya jiwa kadangkala diartikan sebagai sesuatu yang berbentuk fisik yang materil melekat pada diri manusia, tampak dan tidak tersembunyi, tetapi pada waktu lain ia mengandung arti sebagai sesuatu yang berbentuk non-materil, yang mengalir pada diri fisik manusia sebagai jauhar(substansi), substansi ruh ataupun substansi berfikir.

Sebelum membicarakan pandangan-pandangan mereka tentang jiwa dan hubungan jiwa dan ruh, akan diuraikan terlebih dahulu apa itu ruh.

Ensiklopedi bahasa Arab, kata yang berakar pada (ra-wa-ḥa) memiliki keluasan makna dan keumuman hukum. Al-rịh, misalnya, artinya hembusan angin, al-rauhu berarti rahmat, al-raihah artinya bau yang harum. Sedangkan rūh itu sendiri memiliki makna yang banyak, di antaranya: kegembiraan, Al-Qur'an, perintah, wahyu, Jibril, Isa, jiwa, dan lain-lain (Ibn Manżūr, 1993: 522-523). 


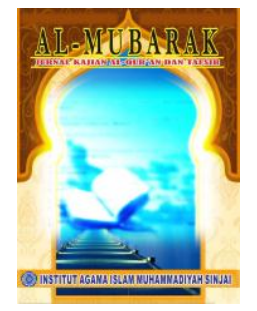

Al-MUBARAK

Jurmall Kajian Al-Quran \& Tafsir

Volume 4, No. 2, 2019

P-ISSN: 2548-7248

E-ISSN: 2715-5692

Homepage : http://journal.iaimsinjai.ac.id/indeks.php/al-mubarak

Menurut al-Qusyairi, ruh, jiwa, dan badan adalah satu komponen (jumlah)

yang membentuk manusia, yang sebagiannya tunduk kepada sebagian yang lain (Al-Imām al-Qusyairi, t.th.: 57). Di kalangan ulama ahlu al-sunnah, terkadang mereka sepakat tentang jiwa dan ruh dalam satu aspek, tetapi ia berbeda pada aspek yang lain. Al-Qusyairy mencontohkan Ibnu Abbas dan Ibnu Habīb, keduanya sepakat bahwa ruh adalah kehidupan atau sumber kehidupan. Keduanya juga sepakat bahwa jiwalah yang diwafatkan saat manusia sedang tidur. Tetapi menurut Ibnu Habib jiwa adalah syahwatiah (kesyahwatan) yang merasakan kelezatan dan merasakan sakit, Sedangkan Ibnu Abbas menganggapnya sebagai akal yang mengetahui, membedakan dan memerintah (Al-Imām al-Qusyairi, t.th.: 57). Pendapat keduanya tentang jiwa yang diwafatkan saat manusia tidur ditentang oleh sebagian muhaqqiq ahlu al-sunnah yang berpendapat bahwa ruh-lah yang berpisah dan terangkat saat manusia sedang tidur dan bukan jiwa.

Menurut Ibnu Zakariya (w. 395 H / 1004 M) menjelaskan bahwa kata alrụh dan semua kata yang memiliki kata aslinya terdiri dari huruf ra-wa-ha; mempunyai arti dasar besar, luas dan asli. Makna itu mengisyaratkan bahwa alruh merupakan sesuatu yang agung, besar dan mulia, baik nilai maupun kedudukannya dalam diri manusia.

Al-Raqib al-Asfahaniy (w. 503 H / 1108 M), menyatakan di antara makna al-rūh adalah al-Nafs (jiwa manusia). Makna disini adalah dalam arti aspek atau dimensi, yaitu bahwa sebagian aspek atau dimensi jiwa manusia adalah al-rūh.

Nyawa (ruh) menurut al-Ghazali mengandung dua pengertian, pertama: tubuh halus (jism latifif). Sumbernya itu lubang hati yang bertubuh. Lalu bertebar dengan perantaraan urat-urat yang memanjang ke segala bagian tubuh yang lain. Mengalirnya dalam tubuh, membanjirnya cahaya hidup, perasaan, penglihatan, pendengaran, dan penciuman dari padanya kepada anggota-anggotanya itu, menyerupai membanjirnya cahaya dari lampu yang berkeliling pada sudut-sudut rumah. Sesungguhnya cahaya itu tidak sampai kepada sebagian dari rumah, melainkan terus disinarinya dan hidup itu adalah seperti cahaya yang kena pada 


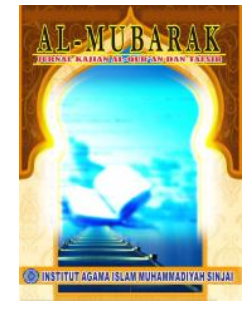

Al-MUBARAK

Jurnall Kajian Al-Quran \& Tafsir

Volume 4, No. 2, 2019

P-ISSN: 2548-7248

E-ISSN: 2715-5692

Homepage : http://journal.iaimsinjai.ac.id/indeks.php/al-mubarak

dinding. Dan nyawa itu adalah seperti lampu. Berjalannya nyawa dan bergeraknya pada batin adalah seperti bergeraknya lampu pada sudut-sudut rumah, dengan digerakkan oleh penggeraknya.

Pengertian kedua yaitu yang halus dari manusia, yang mengetahui dan yang merasa. Dan itulah tentang salah satu pengertian hati, serta itulah yang dikehendaki oleh Allah Ta'ala dengan firman-Nya dalam QS al-Isrā'/17: 85,

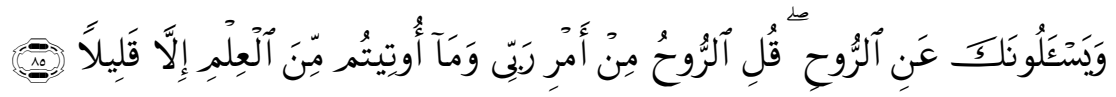

Terjemahnya:

"Dan mereka bertanya kepadamu tentang roh. Katakanlah: "Roh itu termasuk urusan Tuhan-ku, dan tidaklah kamu diberi pengetahuan melainkan sedikit".

Dan itu adalah urusan ketuhanan yang menakjubkan, yang melemahkan kebanyakan akal dan paham dari pada mengetahui hakikatnya.

Penjelasan di atas, dapat disimpulkan bahwa jiwa adalah sesuatu yang maujüd (ada), tetapi bagaimana wujudnya? Inilah yang berbeda di kalangan para filosof, theolog, ahlu al-sunnah dan tasawwuf. Jika sebagian golongan ahlu alhadis dan tasawwuf meyakini jiwa berbeda dengan ruh, maka sebagian yang lain dari para filosof muslim justru menganggap jiwa dan ruh itu adalah sinonim. Letak perbedaan tersebut bisa dipahami karena adanya perbedaan pada disiplin ilmu. sehingga berbeda pula sudut pandangnnya. Lantas bagaimana al-Qur'an berbicara tentang jiwa dan ruh? Mungkinkah perbedaan tersebut dipertemukan dengan kembali kepada al-Qur'an?

\subsection{Jiwa dan Ruh dalam al-Qur'an}

Kata nafs di dalam al-Qur'an disebutkan lebih dari 250 kali dengan berbagai varian (perubahan) katanya. Antaranya al-fi ‘l (kata kerja) seperti إذا تنفس al-ism (kata benda), baik isim al-nakirah, isim ma'rifah, mufrad ataupun jama', serta yang bergandengan dengan ḍmïr seperti أنفسكم , نفسي. jumlahnya yang lebih dari dua ratus lima puluh kali, dapat dipastikan bahwa lafal al-nafs mempunyai arti yang lebih dari satu dan maksud yang beragam. Jika ditelusuri dalam Al- 


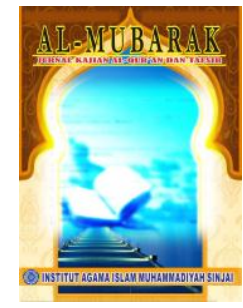

\section{Al-MUBARAK}

Jurnal Kajian Al-Quran \& Tafsir

Volume 4, No. 2, 2019

P-ISSN: 2548-7248

E-ISSN: 2715-5692

Homepage : http://journal.iaimsinjai.ac.id/indeks.php/al-mubarak

Qur'an, kata al-nafs mempunyai beberapa arti, yaitu antara lain: (Amir al-Najjär, 2001: 36-37).

a. Bermakna al-insān (manusia), seperti dalam:

1. QS al-Mā'idah/5: 32:

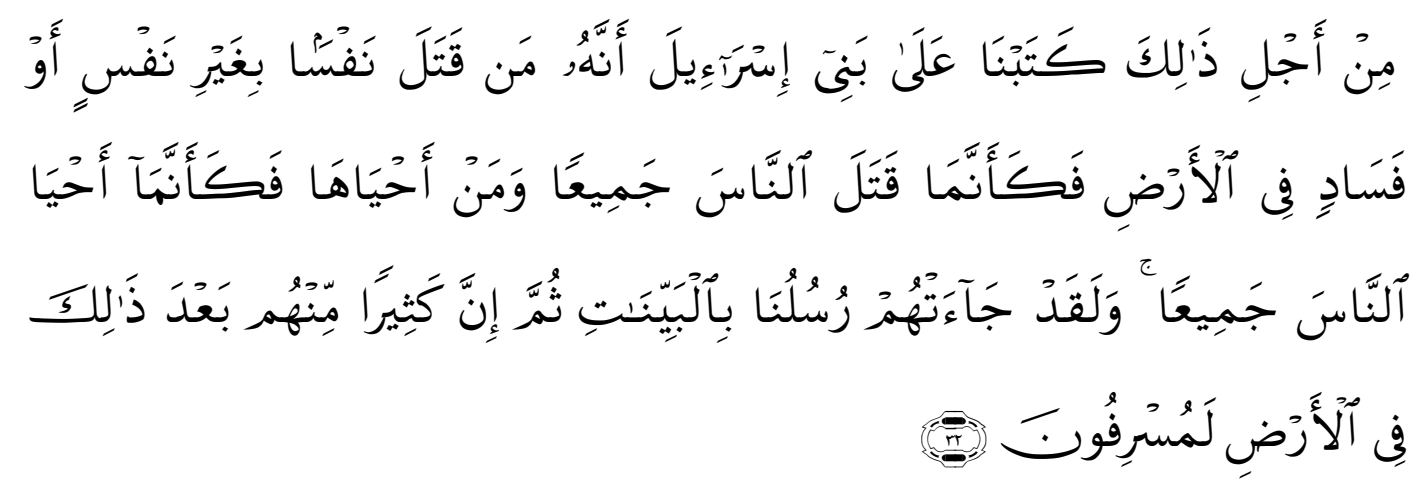

Terjemahnya:

"Oleh karena itu Kami Tetapkan (suatu hukum) bagi Bani Israil, bahwa barangsiapa membunuh seseorang, bukan karena orang itu membunuh orang lain, atau bukan karena berbuat kerusakan di bumi, maka seakanakan dia telah membunuh semua manusia. Barangsiapa memelihara kehidupan seorang manusia, maka seakan-akan dia telah memelihara kehidupan semua manusia. Sesungguhnya Rasul Kami telah datang kepada mereka dengan (membawa) keterangan-keterangan yang jelas. Tetapi kemudian banyak di antara mereka setelah itu melampaui batas di bumi."

2. QS al-Baqarah/2: 48,

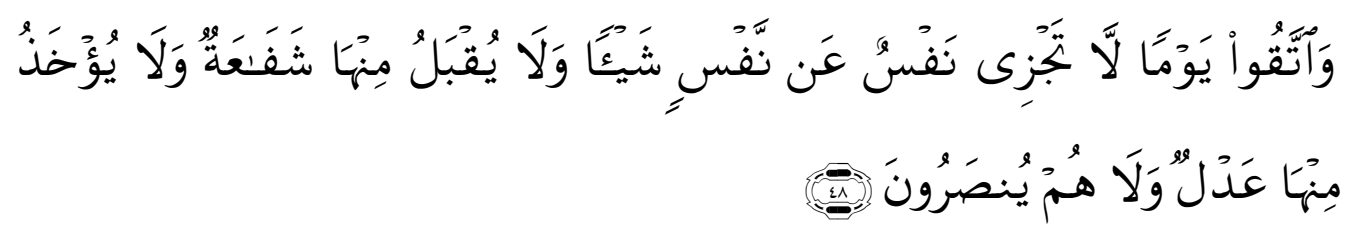

Terjemahnya:

Dan takutlah kamu pada hari, (ketika) tidak seorang pun dapat membela orang lain sedikit pun. Sedangkan syafaat dan tebusan apa pun darinya tidak diterima dan mereka tidak akan ditolong.

b. Bermakna Zat Ilahiyah, seperti firman Allah dalam:

1. QS Ṭāhā/20: 41:

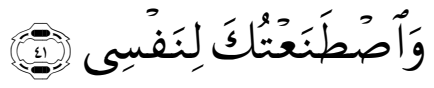

Terjemahnya:

"Dan aku telah memilihmu (menjadi rasul) untukku." 


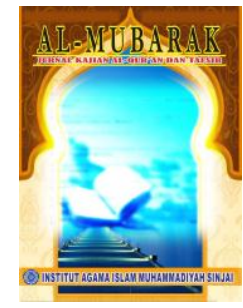

Volume 4, No. 2, 2019

P-ISSN: 2548-7248

E-ISSN: 2715-5692

Homepage : http://journal.iaimsinjai.ac.id/indeks.php/al-mubarak

2. QS al-An'ām/6: 12:

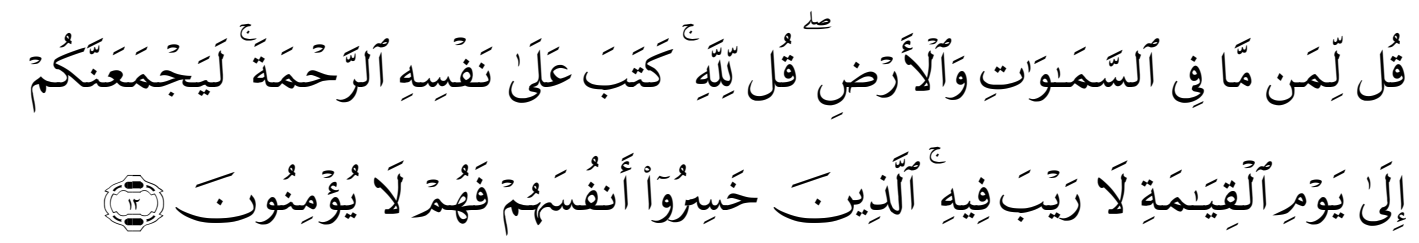

Terjemahnya:

"Katakanlah (Muhammad), "Milik siapakah apa yang di langit dan di bumi?" Katakanan, "Milik Allah." Dia telah Menetapkan (sifat) kasih sayang pada diri-Nya.** Dia sungguh akan Mengumpulkan kamu pada hari Kiamat yang tidak diragukan lagi. Orang-orang yang merugikan dirinya, mereka itu tidak beriman."

c. Bermakna isyarat terhadap apa yang tersirat di dalam jiwa manusia, seperti dalam firman-Nya:

1. QS al-Ra'd/13: 11:

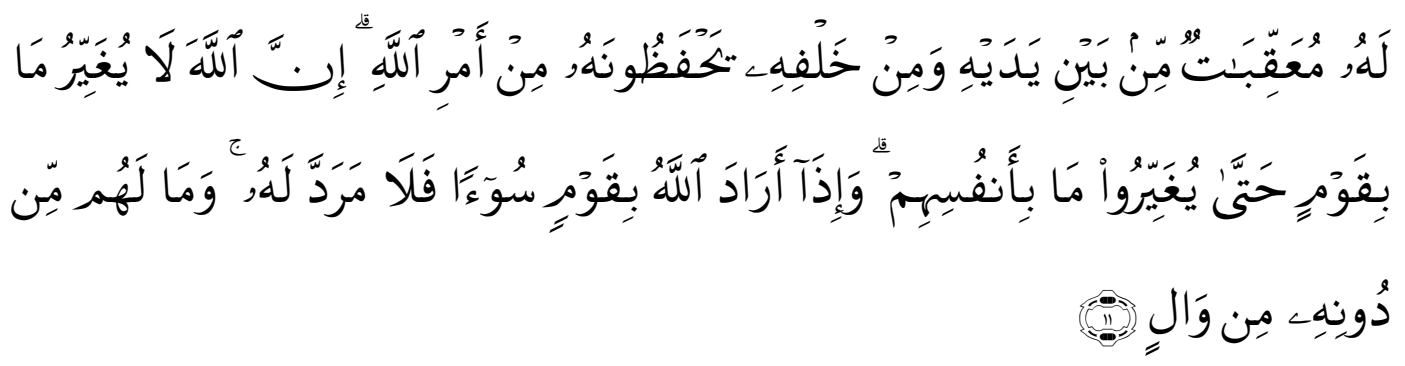

Terjemahnya:

Baginya (manusia) ada malaikat-malaikat yang selalu menjaganya bergiliran, dari depan dan belakangnya. Mereka menjaganya atas perintah Allah. Sesungguhnya Allah tidak akan mengubah keadaan suatu kaum sebelum mereka mengubah keadaan diri mereka sendiri. Dan apabila Allah Menghendaki keburukan terhadap suatu kaum, maka tak ada yang dapat menolaknya dan tidak ada pelindung bagi mereka selain Dia.

2. QS Qāf/50: 16:

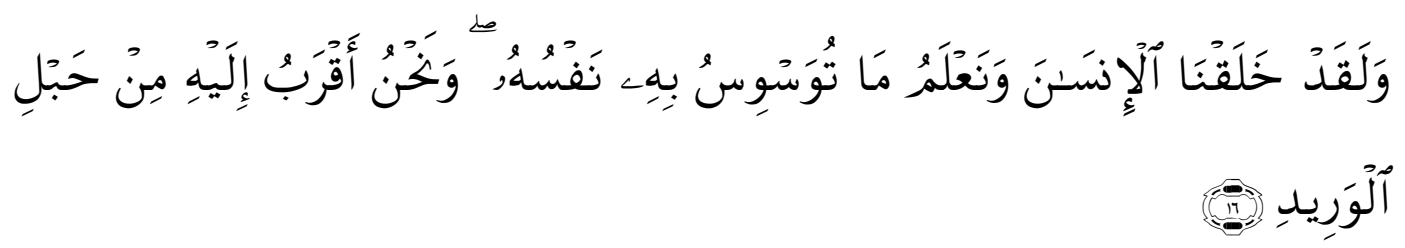

Terjemahnya:

"Dan sungguh, Kami telah Menciptakan manusia dan Mengetahui apa yang dibisikkan oleh hatinya, dan Kami lebih dekat kepadanya daripada urat lehernya." 


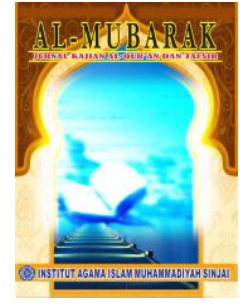

\section{Al-MUBARAK}

Jurnall Kajian Al-Quran \& Tafsir

Volume 4, No. 2, 2019

P-ISSN: 2548-7248

E-ISSN: 2715-5692

Homepage : http://journal.iaimsinjai.ac.id/indeks.php/al-mubarak

d. Bermakna satu asal keturunan manusia, seperti dalam firman-Nya:

1. QS al-Nisā'/4: 1:

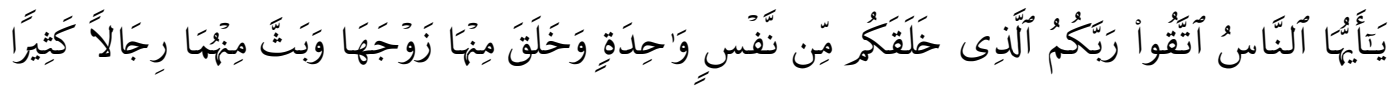

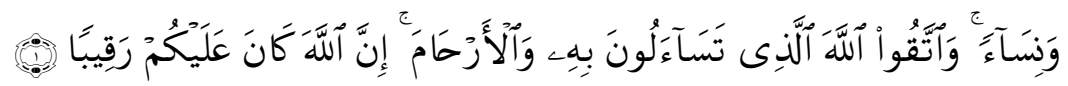

Terjemahnya:

"Wahai manusia! Bertakwalah kepada Tuhan-mu yang telah Menciptakan kamu dari diri yang satu (Adam), dan (Allah) Menciptakan pasangannya (Hawa) dari (diri)-nya; dan dari keduanya Allah Memperkembangbiakkan laki-laki dan perempuan yang banyak. Bertakwalah kepada Allah yang dengan nama-Nya kamu saling meminta, dan (peliharalah) hubungan kekeluargaan. Sesungguhnya Allah selalu Menjaga dan Mengawasimu."

e. Dalam hubungannya dengan makna substansi manusia yang dijabarkan dengan bentukpenyebutan nafsu-nafsu seperti nafsu ammārah, nafsu lawwāmah dan nafsu mutma'innah, sebagaimana firman Allah sebagai berikut:

1. QS Yūsuf/12: 53,

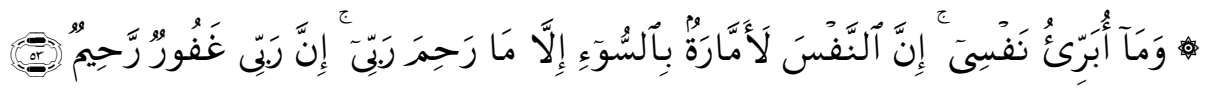

Terjemahnya:

"Dan aku tidak (menyatakan) diriku bebas (dari kesalahan), karena sesungguhnya nafsu itu selalu mendorong kepada kejahatan, kecuali (nafsu) yang Diberi rahmat olehTuhan-ku. Sesungguhnya Tuhan-ku Maha Pengampun, Maha Penyayang."

2. QS al-Fajr/89: 27:

Terjemahnya:

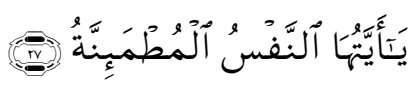

"Hai jiwa yang tenang".

Kata al-rūh dengan keseluruhan perubahan kata dari kata asalnya disebutkan sebanyak 53 kali. Sedangkan kata rūh sendiri disebutkan 21 kali dalam 20 ayat (Muhammad Fu'ād 'Abd al-Bāqī, 2001: 400).

Kata al-rūh dalam al-Qur'an memiliki beberapa makna, antara lain:

a. Rahasia Tuhan yang diletakkan pada diri manusia, seperti QS al-Sajadah/32: 9: 


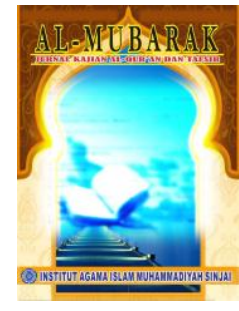

\section{Al-MUBARAK}

Jurnal Kajian Al-Quran \& Tafsir

Volume 4, No. 2, 2019

P-ISSN: 2548-7248

E-ISSN: 2715-5692

Homepage : http://journal.iaimsinjai.ac.id/indeks.php/al-mubarak

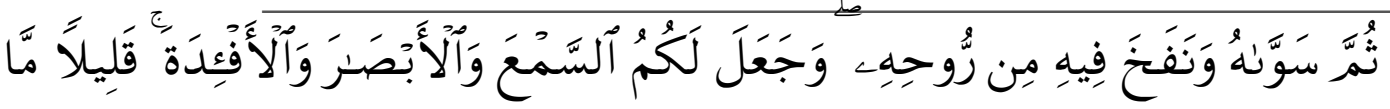

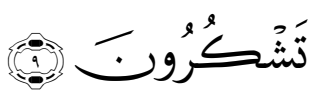

Terjemahnya:

"Kemudian Dia Menyempurnakannya dan Meniupkan roh (ciptaan)-Nya ke dalam (tubuh)nya dan Dia Menjadikan pendengaran, penglihatan dan hati bagimu, (tetapi) sedikit sekali kamu bersyukur".

b. Rüh al-amīn atau malaikat Jibril, seperti QS al-Mà'idah/5: 110:

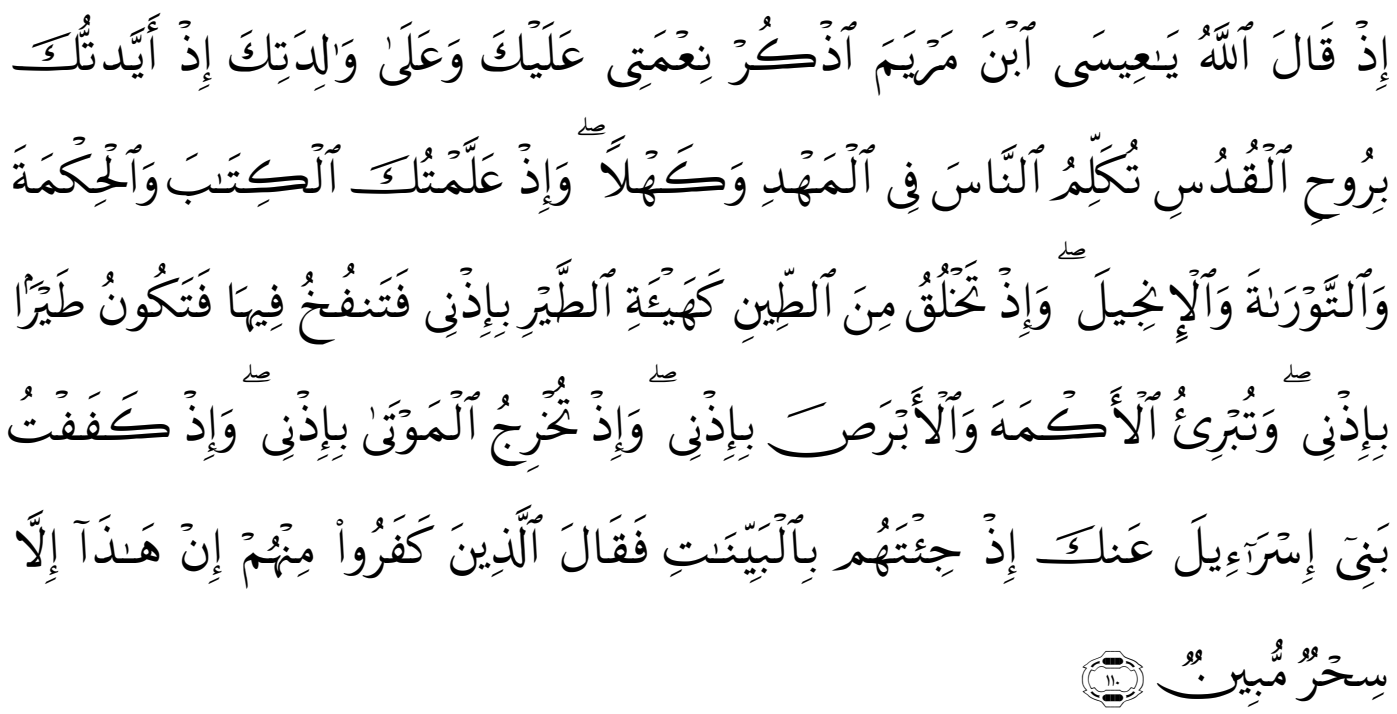

Terjemahnya:

"Dan ingatlah, ketika Allah Berfirman, "Wahai 'Isa putra Maryam! Ingatlah nikmat-Ku kepadamu dan kepada ibumu sewaktu Aku Menguatkanmu dengan Ruhul Qudus. Engkau dapat berbicara dengan manusia di waktu masih dalam buaian dan setelah dewasa. Dan ingatlah ketika Aku Mengajarkan menulis kepadamu, (juga) Hikmah, Taurat dan Injil. Dan ingatlah ketika engkau membentuk dari tanah berupa burung dengan seizin- $\mathrm{Ku}$, kemudian engkau meniupnya, lalu menjadi seekor burung (yang sebenarnya) dengan seizin-Ku. Dan ingatlah, ketika engkau menyembuhkan orang yang buta sejak lahir dan orang yang berpenyakit kusta dengan seizin-Ku. Dan ingatlah ketika engkau mengeluarkan orang mati (dari kubur menjadi hidup) dengan seizin-Ku. Dan ingatlah ketika Aku Menghalangi Bani Israil (dari keinginan mereka membunuhmu) dikala engkau mengemukakan kepada mereka keterangan-keterangan yang nyata, lalu orang-orang kafir di antara mereka berkata, "Ini tidak lain hanyalah sihir yang nyata". 


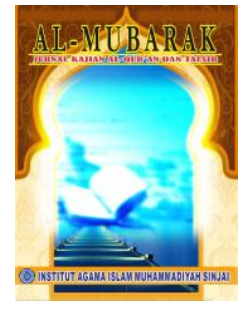

\section{Al-MUBARAK}

Jurnall Kajian Al-Quran \& Tafsir

Volume 4, No. 2, 2019

P-ISSN: 2548-7248

E-ISSN: 2715-5692

Homepage : http://journal.iaimsinjai.ac.id/indeks.php/al-mubarak

c. Sebagian Malaikat, seperti QS al-Ma‘ārij/70: 4:

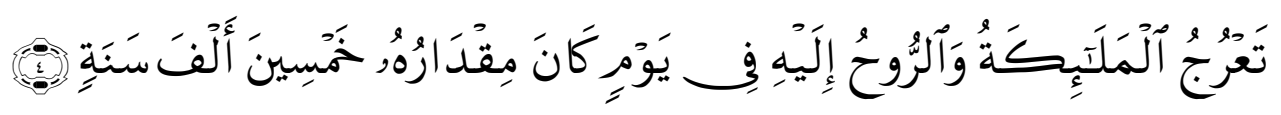

Terjemahnya:

"Para malaikat dan Jibril naik (menghadap) kepada Tuhan, dalam sehari setara dengan lima puluh ribu tahun".

d. Kekuatan dari Allah, seperti QS al-Nisā'/4: 171:

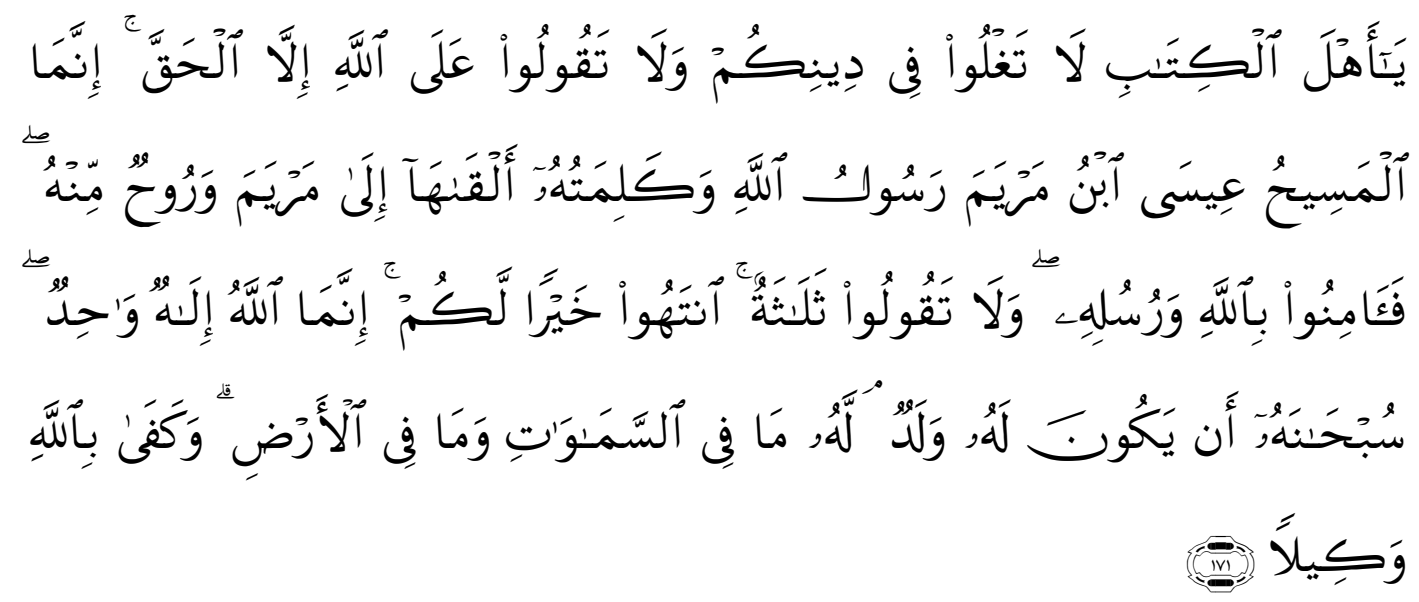

Terjemahnya:

"Wahai ahli kitab, janganlah kamu melampaui batas dalam agamamu, dan janganlah kamu mengatakan terhadap Allah kecuali yang benar. Sesungguhnya Al Masih, Isa putera Maryam itu, adalah utusan Allah dan (yang diciptakan dengan) kalimat-Nya yang disampaikan-Nya kepada Maryam, dan (dengan tiupan) roh dari-Nya. Maka berimanlah kamu kepada Allah dan rasul-rasul-Nya dan janganlah kamu mengatakan: "(Tuhan itu) tiga", berhentilah (dari Ucapan itu). (itu) lebih baik bagimu. Sesungguhnya Allah Tuhan yang Maha Esa, Maha Suci Allah dari mempunyai anak, segala yang di langit dan di bumi adalah kepunyaan-Nya. cukuplah Allah menjadi Pemelihara".

e. Wahyu atau Al-Qur'an, seperti QS al-Nahl/16: 2:

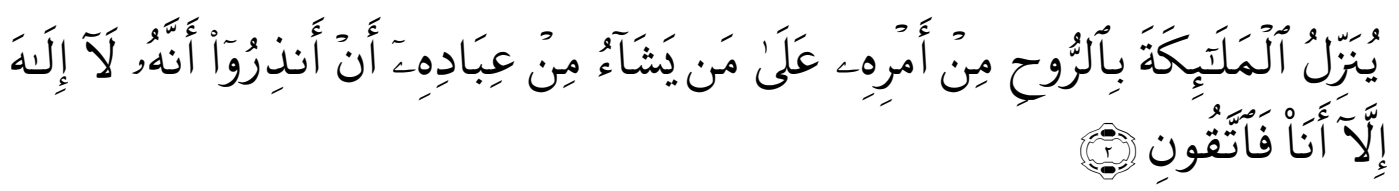

Terjemahnya:

"Dia Menurunkan para malaikat membawa wahyu dengan perintahNya kepada siapa yang Dia Kehendaki di antara hamba-hamba-Nya, (dengan Berfirman) yaitu, "Peringatkanlah (hamba-hamba-Ku), 


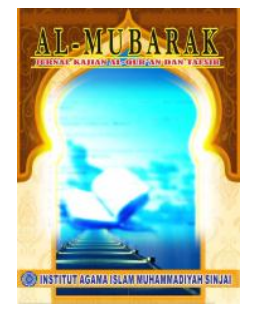

Al-MUBARAK

Jurmall Kajian Al-Quran \& Tafsir

Volume 4, No. 2, 2019

P-ISSN: 2548-7248

E-ISSN: 2715-5692

Homepage : http://journal.iaimsinjai.ac.id/indeks.php/al-mubarak

bahwa tidak ada tuhan seain Aku, maka hendaklah kamu bertakwa kepada-Ku".

Memperhatikan ayat-ayat al-Qur'an yang berbicara tentang al-nafs jumlahnya jauh lebih banyak dari pada al-rụh. Dalam beberapa ayat, ketika Tuhan menyebut kata al-nafs, yang dimaksudkan di dalamnya adalah al-rūh (misalnya QS al-Fajr/89: 27). Sebab itu, maka dapat disimpulkan, bahwa hakekat al-nafs (jiwa) berasal dari al-rūh. Ruh adalah inti dan jiwa adalah bagian dari alrūh. Hal tersebut didasari dengan beberapa alasan;

1) Kata al-rūh (ruh) di dalam al-Qur'an selalu disebutkan dengan bentuk mufrad (tunggal), al-rūḥ, tidak ada yang berbentuk jamak (al-arwāḥ). Berbeda dengan kata al-nafs disebutkan dalam bentuk tunggal maupun jamak.

2) Tidak ada kata al-rūh di dalam al-Qur'an yang secara eksplisit menunjuk pada arti ruh itu sendiri, ataupun jiwa. Ketika Allah menyebut al-rūh, yang dimaksudkan justru malaikat Jibril, kekuatan dari-Nya, atau al-Qur'an. Ini menunjukkan bahwa kata al-rūḥ digunakan pada sesuatu yang lebih utama dari sekadar dipahami secara sederhana sebagai hembusan nafas, atau substansi yang mewujudkan proses hidup tubuh manusia. Al-rūh (dalam makna ruh Tuhan, al-Qur'an atau malaikat Jibril) adalah hakekat yang menjadi sumber kehidupan manusia yang sempurna, asal segala kehidupan, yang memancarkan sinaran petunjuk kepada jiwa yang berkelana dalam kehidupan fisik manusia.

3) Semua kata al-rūh merupakan ungkapan transenden Tuhan, bahkan beberapa ayat, ketika Allah Swt menyebut kata al-rūh, Ia mengaitkannya dengan diriNya (rūhịy), ini menunjukkan bahwa ruh memiliki unsur ketuhanan di dalamnya. Berbeda dengan kata al-nafs, Allah Swt menyebutkannya dengan sangat plural, hingga mengklasifikasikan berdasarkan kualitasnya, kehidupan baik maupun kehidupan buruk. Sebab itu jiwa memiliki unsur ketuhanan sekaligus memiliki unsur syaitaniyah. Dua ranah kehidupan dalam diri manusia yang selalu bertarung sepanjang hidupnya. Siapa pemenang, dialah yang akan menentukan pilihan dan mengendalikan tindakan.

Beberapa ayat menyebutkan kata al-nafs dengan arti ruh, yang berkaitan langsung dengan jasad manusia sebagai komponen fisik manusia. pada aspek ini 


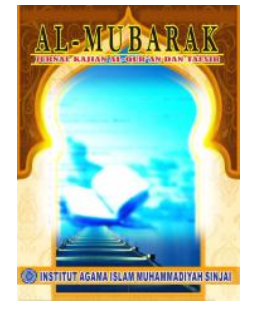

Al-MUBARAK

Jurnall Kajian Al-Quran \& Tafsir

Volume 4, No. 2, 2019

P-ISSN: 2548-7248

E-ISSN: 2715-5692

Homepage : http://journal.iaimsinjai.ac.id/indeks.php/al-mubarak

kata al-rūh dengan al-nafs memiliki kedekatan makna, al-nafs berarti bernafas dan al-rụh yang jika di jamakkan, al-arwăh, adalah penentu hidup atau matinya manusia. Bahasa keseharian, jika ia tidak bernafas lagi maka ruhnya sudah tiada. Sebab itu pertanyaan apakah ruh dan jiwa sama atau berbeda? Penulis lebih cenderung memilih pendapat yang mengatakan bahwa perbedaan ruh dan jiwa adalah perbedaan sifat, bukan zat (Ibn al-Qayyim al-Jauziyah, t.th.: 213).

Jiwa juga punya gerak, sebab itu manusia jika ia tidur jiwanya bisa keluar dari jasad dan melayang-layang, tetapi ruhnya tetap ada dan mengatur pola tanaffus-nya (keluar masuknya nafas), tetapi ia tidak sadar karena jiwanya sedang di luar jasad, dan akan datang kembali ke dalam jasad dengan kecepatan yang tak terbahasakan jika Allah menghendakinya kembali (Lihat QS alZumar/39: 42).

\subsection{Apakah Roh itu Makhluk?}

Tidak ada perbedaan pendapat di kalangan kaum muslimin bahwa roh-roh pada diri Adam, Isa, anak keturunannya dan siapapun semuanya adalah makhluk Allah yang diciptakan, disempurnakan, diadakan, dibentuk, lalu dikaitkan dengan diri-Nya. Sebagaimana dengan makhluk-makhluk Allah Swt yang lain semuanya dalam kuasa-Nya dan tunduk atas kehendak-Nya. Firman Allah dalam QS alJasiiyah/45: 13,

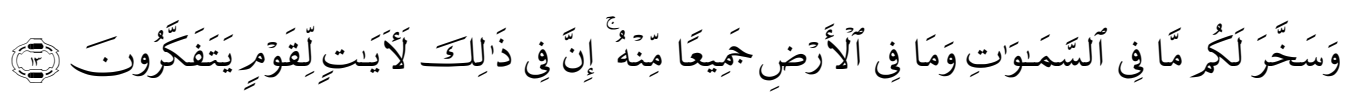

Terjemahnya:

"Dan dia menundukkan untuk kalian apa yang ada di langit dan di bumi semuanya, sebagai rahmat dari-Nya."

Ibnu Taimiyah berkata roh anak Adam adalah makhluk yang diciptakan. Begitulah kesepakatan dari ummat ini, para imam Ahlussunnah. Meskipun demikian, ada beberapa kalangan dari ummat ini yang berpendapat bahwa roh itu lama dan tidak diciptakan.

Menurut Ibnu Qayyim ada banyak hal yang menujukkan bahwa roh itu adalah makhluk yang diciptakan antara lain:

a. Firman Allah Swt dalam QS al-Ra'd/13: 16, 


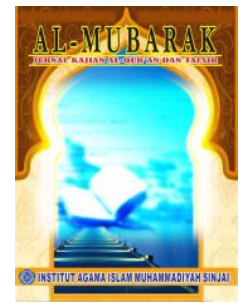

\section{Al-MUBARAK}

Jurmall Kajian Al-Quran \& Tafsir

Volume 4, No. 2, 2019

P-ISSN: 2548-7248

E-ISSN: 2715-5692

Homepage : http://journal.iaimsinjai.ac.id/indeks.php/al-mubarak

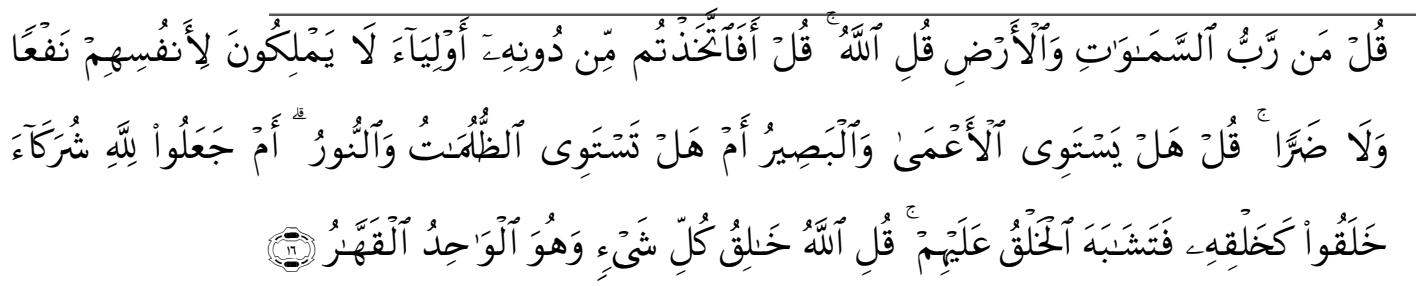

Terjemahnya:

"Katakanlah (Muhammad), "Siapakah Tuhan langit dan bumi?" Katakanlah, "Allah.” Katakanlah, "Pantaskah kamu mengambil pelindungpelindung selain Allah, padahal mereka tidak kuasa mendatangkan manfaat maupun menolak mudarat bagi dirinya sendiri?" Katakanlah, "Samakah orang yang buta dengan yang dapat melihat? Atau samakah yang gelap dengan yang terang? Apakah mereka menjadikan sekutu-sekutu bagi Allah yang dapat menciptakan seperti ciptaan-Nya sehingga kedua ciptaan itu serupa menurut pandangan mereka?" Katakanlah, "Allah adalah Pencipta segala sesuatu dan Dia Tuhan Yang Maha Esa, Maha Perkasa."

Dalam ayat di atas jelaslah bahwa Allah Swt dengan sifat-sifatnya adalah khaliq, sedangkan selainnya adalah makhluk yang diciptakan-Nya. Dengan demikian dapat diketahui secara pasti bahwa roh adalah sesuatu yang diciptakan.

b. Firman Allah kepada Zakaria dalam QS Maryam/19: 9,

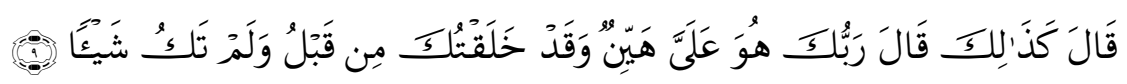

Terjemahnya:

“(Allah) Berfirman, "Demikianlah.” Tuhan-mu Berfirman, "Hal itu mudah bagi-Ku; sungguh, engkau telah Aku Ciptakan sebelum itu, padahal (pada waktu itu) engkau belum berwujud sama sekali."

c. Firman Allah Swt dalam QS Ash Shaffat/37: 96,

$$
\text { وَالْلَّهُ خَلَفَكُمُ وَمَا تَعْمَلُونَ }
$$

Terjemahnya:

"Dan Allah menciptakan kamu sekalian sedang kalian tidak mengetahui."

d. Firman Allah dalam QS al-A'raf yang artinya sesungguhnya kami telah menciptakan kalian, lalu kami bentuk tubuh kalian, kemudian kami katakan kepada para malaikat, bersujudlah kalian kepada Adam. Penggambaran ini mencakup roh dan badan, sebagaimana yang dikatakan jumhur ulama.

e. Roh dan badan adalah dalam kekuasaan Allah Swt, apapun yang dikuasai dan dimiliki maka dia adalah ciptaan. 


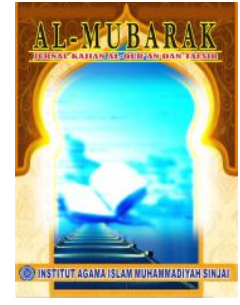

Al-MUBARAK

Jurmall Kajian Al-Quran \& Tafsir

Volume 4, No. 2, 2019

P-ISSN: 2548-7248

E-ISSN: 2715-5692

Homepage : http://journal.iaimsinjai.ac.id/indeks.php/al-mubarak

f. Banyak nash yang menunjukkan bahwa manusia secara keseluruhannya adalah hamba. Ubudiyahnya tidak hanya berlaku bagi badan tanpa roh, bahkan ubudiyah roh merupakan dasar ubudiyah badan.

g. Firman Allah dalam QS al-Insān/76: 1,

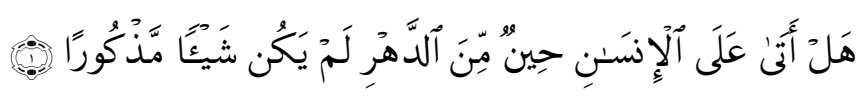

Terjemahnya:

"Bukankah pernah datang kepada manusia waktu dari masa, yang ketika itu belum merupakan sesuatu yang dapat disebut?"

h. Roh disifati dengan kematian, pencabutan, penahanan, pemegangan dan pembebasan sebagaimana QS al-Zumar/39: 42,

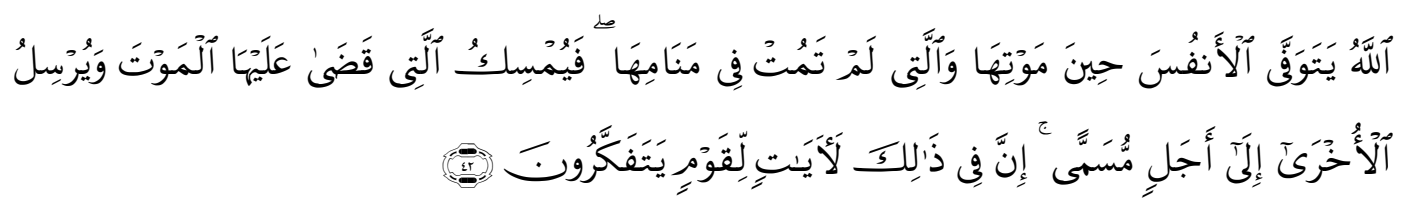

Terjemahnya:

"Allah memegang nyawa (seseorang) pada saat kematiannya dan nyawa (seseorang) yang belum mati ketika dia tidur; maka Dia Tahan nyawa (orang) yang telah Dia Tetapkan kematiannya dan Dia Lepaskan nyawa yang lain sampai waktu yang ditentukan. Sungguh, pada yang demikian itu terdapat tanda-tanda (kebesaran) Allah bagi kaum yang berpikir".

Pengambaran tentang roh yang tidak sanggup mendatangkan mudharat dan manfaat untuk dirinya, tidak pula hidup dan mati tanpa kehendak Allah Swt tidak bisa mengambil dari kebaikan kecuali yang diberikan kepadanya, tidak tertuntun kepada kemaslahatan dunia dan akhirat kecuali menurut etunjuk Allah, tidak menjadi baik kecuali taufik dari Allah, tidak mengetahui kecuali menurut ilmu yang diberikan kepadanya. Allahlah yang menciptakan jiwa atau roh dan menyempurnakannya, mengilhamkan kepadanya jalan kefasikan atau ketakwaan.

Kematian jiwa adalah terpisahnya jiwa itu dari badan dan keluarnya dari sana. Jika yang dimaksud kematiannya dengan gambaran seperti ini, maka memang ai bisa mati. Tapi jika yang dimaksudkan bahwa jiwa itu hilang dan lenyap sama sekali, maka ia tidak mati dengan gambaran ini, tetapi dia tetap dalam kenikmatan dan siksa-Nya, sebagaimana firman Allah Swt dalam QS $\bar{A}$ li 'Imrān/3:169-170, 


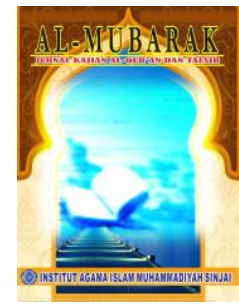

\section{Al-MUBARAK}

Jurmal Kajian Al-Quran \& Tafsir

Volume 4, No. 2, 2019

P-ISSN: 2548-7248

E-ISSN: 2715-5692

Homepage : http://journal.iaimsinjai.ac.id/indeks.php/al-mubarak

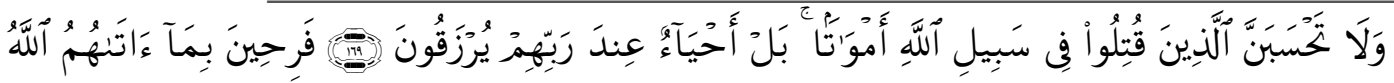

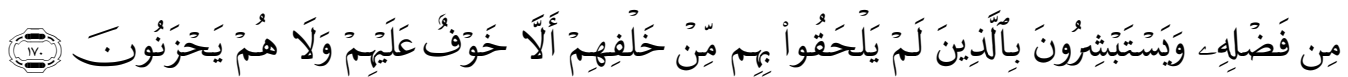

Terjemahnya:

"Dan jangan sekali-kali kamu mengira bahwa orang-orang yang gugur di jalan Allah itu mati; sebenarnya mereka itu hidup, di sisi Tuhan-nya mendapat rezeki, mereka bergembira dengan karunia yang Diberikan Allah kepadanya, dan bergirang hati terhadap orang yang masih tinggal di belakang yang belum menyusul mereka, bahwa tidak ada rasa takut pada mereka dan mereka tidak bersedih hati."

Ada sebuah hadis yang menunjukkan bagaina proses kematian itu terjadi.

Diriwatkan Imam Ahmad, no. 17803 dari Bara bin Azib dari Nabi Saw bersabda:

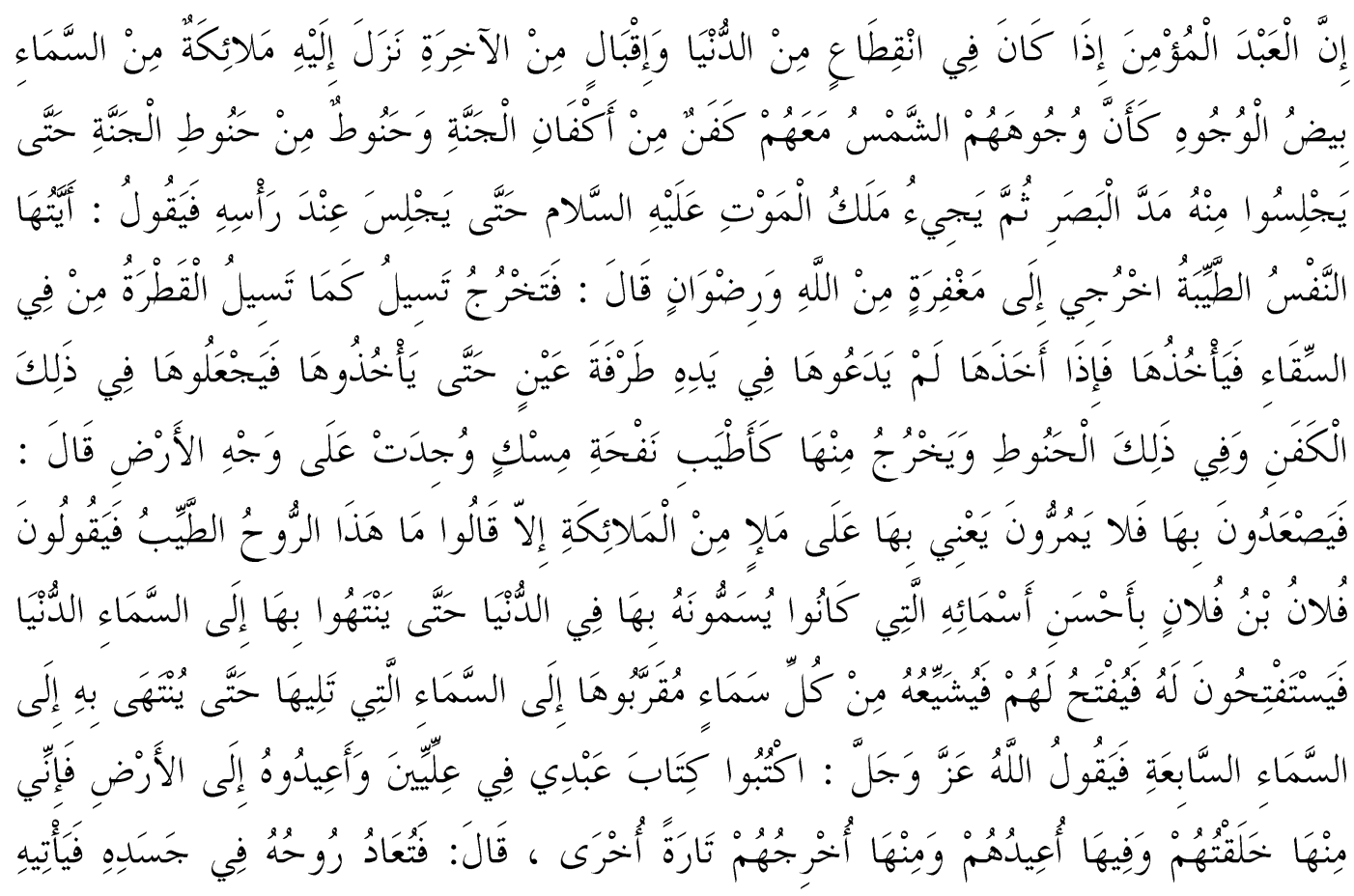
مَلَكَانِ فَيْجْلِسَانِهِ.

Artinya:

"Sesungguhnya seorang hamba yang beriman, ketika terputus dari dunia dan memulai (kehidupan) akhirat, para malaikat turun kepadanya dari langit, wajahnya putih, wajah mereka seperti matahari. Bersamanya kain kafan dari surga dan minyak wangi dari surga. Sampai mereka duduk sejauh mata memandang. Kemudian didatangkan malaikan maut alaihissalam. Lalu dia duduk di kepalanya seraya mengatakan, "Wahai jiwa yang baik, keluarlah menuju ampunan dan keridoan Allah. Maka (ruh) keluar lepas seperti tetasan air yang mengalir dari tempat minuman. Maka dibawanya ruh itu dengan sepenuh perhatian tidak lengah sedikipun. Lalu dibawa dan 


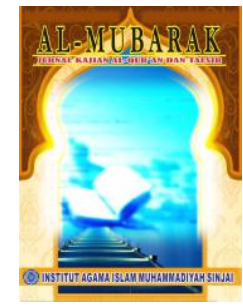

\section{Al-MUBARAK}

Jurmall Kajian Al-Quran \& Tafsir

Volume 4, No. 2, 2019

P-ISSN: 2548-7248

E-ISSN: 2715-5692

Homepage : http://journal.iaimsinjai.ac.id/indeks.php/al-mubarak

diletakkan di kafan itu dengan minyak wangi itu, sehingga keluar darinya bau sangat wangi yang didapatkan di atas bumi. Berkata, "Kemudian dia dibawa naik olehnya, tidaklah melewati sekumpulan malaikat kecuali mereka mengatakan, "Apa gerangan ruh yang baik ini?” mereka menjawab, "Ini fulan bin fulan." dengan menyebutkan nama terbaiknya yang mereka namakan di dunia. Hingga selesai dari langit dunia, lalu mereka meminta izin untuk dibukakan baginya, dan dibukakan untuk mereka, dan setiap makhluk di langit ikut menghantarkan sampai ke langit setelahnya sampai selesai di langit ketujuh. Maka Allah Azza Wajalla berfirman, "Tulislah kitab hamba-Ku ini di Illiyyin dan kembalikan dia ke bumi. Karena Saya ciptakan darinya dan ia dikembalikan dan nanti akan di keluarkan lagi.Maka ruhnya dikembalikan ke jasadnya, sampai datang dua malaikat dan mendudukkannya..." kemudian disebutkan hadits tentang pertanyaan kubur.

Kemudian disebutkan mencabut ruh orang kafir dan mengatakan, "Mereka membawannya. Tidaklah mereka melewati sekumpulan malaikat melainkan mereka mengatakan, "Ruh busuk apa ini." Mereka mengatakan fulan bin fulan, dengan nama terjelek yang mereka namakan di dunia. Sampai ke langit dunia. Dan meminta dibukakan, namun tidak dibukakan untuknya. Kemudian Allah Swt berfirman dalam QS al-A’raf/7: 40,

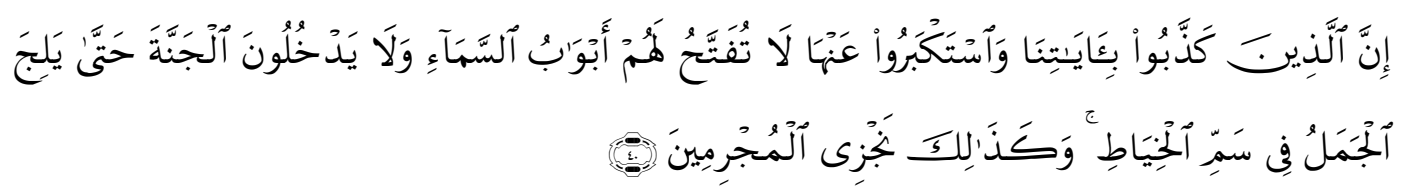

Terjemahnya:

"Sesungguhnya orang-orang yang mendustakan ayat-ayat kami dan menyombongkan diri terhadapnya, sekali-kali tidak akan dibukakan bagi mereka pintu-pintu langit dan tidak (pula) mereka masuk surga, hingga unta masuk ke lubang jarum. Demikianlah kami memberi pembalasan kepada orang-orang yang berbuat kejahatan."

Maka Allah Azza Wajalla berfirman, "Tulislah kitabnya di Sijjin di bumi yang bawah. Kemudian dilemparkan ruhnya begitu saja dan dibacakan ayat QS al-Hajj/22: 31,

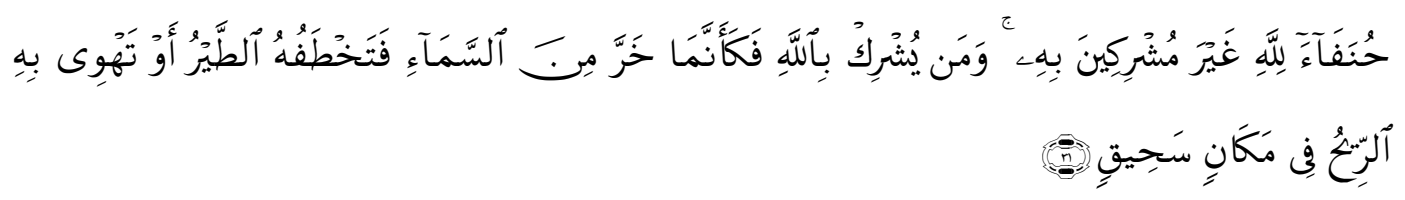




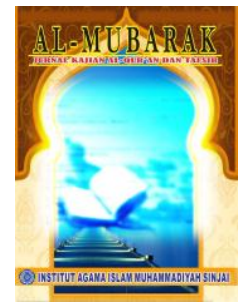

Al-MUBARAK

Jurmall Kajian Al-Quran \& Tafsir

Volume 4, No. 2, 2019

P-ISSN: 2548-7248

E-ISSN: 2715-5692

Homepage : http://journal.iaimsinjai.ac.id/indeks.php/al-mubarak

Terjemahnya:

"Dengan ikhlas kepada Allah, tidak mempersekutukan sesuatu dengan Dia. barangsiapa mempersekutukan sesuatu dengan Allah, Maka adalah ia seolah-olah jatuh dari langit lalu disambar oleh burung, atau diterbangkan angin ke tempat yang jauh."

Menyelaraskannya dengan ajaran Islam. Hal itu karena adanya ayat alQur'an yang menjadi tembok penghalang dalam menyingkap tabir hakekat ruh, di mana hanya Allah Swt. semata yang mengetahui urusan ruh (Sirajuddin Zar, t.th.: 59). Jika ini benar, maka bisa dikatakan, dibalik kesuksesan besar yang telah dicapai para filosof Muslim dalam dunia filsafat, ada kegagalan besar yang telah dilakukan dalam memahami Islam sebagai ajaran yang universal, komprehensif dan integral, dan gagal membangun batu bata ilmu dengan pondasi utamanya al-Qur'an dan sunnah Nabi. Implikasinya, ketika Barat mengadopsi filsafat para filosof Muslim, mereka menerima filsafat tapi terlepas dari nilai Islam yang seharusnya ada, akibatnya mereka kehilangan nilai spiritual. Kenyataan inilah yang disadari oleh al-Gazāli sehingga meluncurkan buku Taḥāfat al-Falāsifah sebagai upaya pelurusan filsafat.

\section{Simpulan}

Berdasarkan uraian penelitian di atas, maka dapat ditarik beberapa kesimpulan sebagai berikut: Pertama, jiwa adalah sesuatu yang maujūd (ada). sebagai sesuatu yang berbentuk non-materil, yang mengalir pada diri fisik manusia yang menjadi sebab manusia menjadi hidup. Kedua, kata jiwa (al-nafs) disebutkan dalam al-Qur'an dengan jumlah lebih dari dua ratus lima puluh kali jauh lebih banyak dari pada kata al-rūh. Kata al-nafs kadang diartikan dengan ruh, dan tidak dengan sebaliknya, ini menunjukkan bahwa hakekat al-nafs (jiwa) berasal dari ruh. Ruh adalah inti dan jiwa adalah bagian dari ruh. Ketiga, jiwa adalah makhluk yang diciptakan dan bukan merupakan bahagian dari dzat Allah Swt.

\section{Daftar Pustaka}

Al-Qur'an al-Karim 


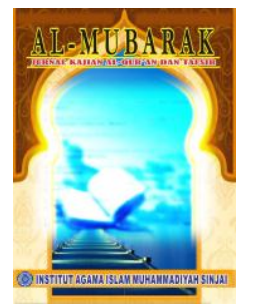

\section{Al-MUBARAK}

Jurnal Kajian Al-Quran \& Tafsir

Volume 4, No. 2, 2019

P-ISSN: 2548-7248

E-ISSN: 2715-5692

Homepage : http://journal.iaimsinjai.ac.id/indeks.php/al-mubarak

'Abd al-Bāqi. (2001). Muhammad Fu'ād. Al-Mu'jam al-Mufahras li Alfāz alQur’ān al-Karìm. Kairo: Dār al-Hadì̀.

Abū al-Dahab, Asyraf Ṭāhā. (2002). Al-Mu'jam al-Islāmī. Kairo: Dār al-Syurūq.

Abū Rayyah, Muhammad 'Ali. (t.th.). Al-Falsafat al-Islämiyyah, Syakhșiyyatuh wa Mażāhibuh. Alexandria: Maktabat al-Iskandariyah.

Daudy, Ahmad. (1983). Allah dan Manusia dalam Konsepsi Syekh Nuruddin arRaniry. Jakarta: Rajawali.

Departemen Agama RI. (1995). Al-Qur'an dan Terjemahnya. Semarang: Karya Toha Putra.

Ibn Manżūr. (1993). Lisān al-Lisān; Taḥżỉb Lisān al-'Arab. Beirut: Dār al-Kutub al-'Ilmiyah.

Ibn Zakariyā', Abū al-Husain Aḥmad ibn Fāris. (t.th.). Mu'jam Maqāyīs alLughah. tt: Dār al-Fikr.

Al-Jauziyah, Ibn al-Qayyim. (1999). Al-Rūh. Singapura/Jeddah/Indonesia: alHaramain, edisi terjemahan: Pustaka Al-Kautsar.

Al-Najjār, Amīr al-'Ilm al-Nafsī al-Süfiyyah. (2001). Diterjemahkan ke dalam bahasa Indonesia oleh Hasan Abrori dengan Judul Ilmu Jiwa dalam Tasawuf. Jakarta: Pustaka Azzam.

Nasution, Harun. (1992). Falsafat dan Mistisisme dalam Islam. Jakarta: Bulan Bintang.

Al-Qusyairī, Al-Imām. (t.th.). Al-Risālah al-Qusyairiyah. Kairo: Maktabah alSāāih.

Tim Reality. (2008). Kamus Terbaru Bahasa Indonesia. Surabaya: Reality Publisher.

Al-Yāzijī, Kamāl. (1963). Al-Nuṣūṣ al-Falsafiyyah al-Muyassarah. Beirut: Dār al-'Ilm li al-Malāyīn.

Al-Zain, Sāmih 'Āṭif. (1991). Ilm al-Nafs; Ma'rifah al-Nafs al-Insaniyah fi alKitab wa al-Sunnah. Beirut: Dar al-Kitab al-Lubnani.

Zar, Sirajuddin. (2004). Filsafat Islam; Filosof dan Filsafatnya. Jakarta: Rajawali Pers. 